\title{
A r chiv
}

für

\section{pathologische Anatomie und Physiologic \\ und für}

\section{klinische Medicin.}

Herausgegeben

von

Rudolf Virehow.

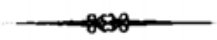

Vierzigster Band.

Dritte Folge: Zehnter Band.

Mit 14 Tafeln.

$$
\text { Berlin, }
$$

Druck und Verlag von Georg Reimer.

1867. 
